\title{
Management of Powdery Mildew of Okra Caused by Erysipheci choracearum
}

\author{
Parag Dahivelkar, G.E. Atre*, P.V. Gawande and G.D. Mate \\ Plant Pathology Section, College of Agriculture, Nagpur, Dr. Punjabrao Krishi \\ Vidyapeeth, Akola, India \\ *Corresponding author
}

\begin{tabular}{|c|c|}
\hline & A B S T R A C T \\
\hline $\begin{array}{l}\text { Key w o r d s } \\
\text { Powdery mildew, } \\
\text { Erysipheci } \\
\text { choracearum, } \\
\text { Okra, } \\
\text { Hexaconazole. }\end{array}$ & \multirow{3}{*}{$\begin{array}{l}\text { Percent disease intensity of powdery mildew of okra revealed significant differences due } \\
\text { to fungicides spray over water and control after spraying. The maximum percent disease } \\
\text { control were recorded with hexaconazole }(87.33 \%) \text { followed by propiconazole } \\
(86.08 \%) \text {. Average yield } \mathrm{q} \mathrm{ha}^{-1} \text { of okra were significantly, influenced due to different } \\
\text { treatments over control treatment. Significantly higher yield of okra obtained with } 0.1 \\
\text { percent hexaconazole } 54.29 \mathrm{q} \mathrm{ha}^{-1} \text { and } 0.1 \text { percent propiconazole } 48.48 \mathrm{q} \mathrm{ha}^{-1} \text { were at par } \\
\text { with each other and significantly superior over rest of treatments. The highest Incremental } \\
\text { cost benefit ratio was recorded by } 0.1 \text { percent hexaconazole } 1: 13.72 \text { followed by } \\
\text { fungicides } 0.3 \text { percent wettable sulphur } 1: 5.62 \text { and } 0.1 \text { percentpropiconazole } 1: 4.84 \text {. From } \\
\text { present investigation, it is concluded that three sprays of hexaconazole @ } 0.1 \text { percent } \\
\text { minimize the intensity } 10.78 \text { percent of disease and achieve yield } 54.29 \mathrm{q} \mathrm{ha}^{-1} \text { with best } \\
\text { ICBR } 1: 13.72 \text { can be use for management of powdery mildew of okra. }\end{array}$} \\
\hline Article Info & \\
\hline $\begin{array}{l}\text { Accepted: } \\
\text { 26 June } 2017 \\
\text { Available Online: } \\
\text { 10 August } 2017\end{array}$ & \\
\hline
\end{tabular}

\section{Introduction}

Okra (Abelmoschus esculentus (L.) Moench), commonly known as lady's finger or 'bhendi' is most delicious vegetable relished world over. It belongs to the family Malvaceae. It is an important vegetable crop of India and Pakistan and its distinguished cultivars are commercially grown in many parts of the world for its unique taste and nutritional value (Benchasri, 2012).Vegetables are important in maintaining satisfactory nutritional level in human diet. Vegetables supply number of vitamins, minerals and organic acids. Besides they also supply carbohydrates for energy and protenous compounds for muscle building. Large quantities of cellulose (fiber) present in vegetables help in digestion and prevents constipation. Dry seeds contain edible oil (13-22\%) and edible protein (20-24\%). In spite of all the good characters in okra vegetable the productivity has been low due to variety of reasons like inadequate use of fertilizers, irrigation and occurrence of various diseases and pests. Numbers of fungal, bacterial, viral diseases have been reported to affect okra crop in India. Diseases are one of the major constraints for low yields of okra (Sastry and Singh, 1974). Fungal diseases viz., powdery mildew (Erysipheci choracearum. DC), leaf blight (Rhizoctonia solani), angular leaf spot (Cercosporaa belmoschi), damping off (Pythium spp., Rhizoctonia spp. and Fusarium spp.) and viral diseases viz., yellow vein mosaic (YVMV), 
bhendi enation mosaic, enation leaf curl are commonly observed. Among these powdery mildew is one of the important disease which reduces the yield considerably.

\section{Materials and Methods}

The experiment on "Management of powdery mildew of okra caused by (Erysipheci choracearum)" was conducted during kharif 2013-14 on the field of Plant pathology Section, College of Agriculture Nagpur. The attempts were made to evaluate the effect of different chemical fungicides on the intensity of powdery mildew of okra, considering the effect of intensity on percent disease control and crop yield. The experiment was laid out in Randomized Block Design with three replication and eight treatments. The okra seed variety Akola Bahar was obtained from Dr. Panjabrao Deshmukh Krishi Vidyapeeth, Akola.

\section{Preparation of spray formulation and application}

Six fungicides were selected viz. Hexaconazole5\% EC @ 0.1\%, Propiconazole 10\% EC @ 0.1\%, Wettable sulphur 80\% WP @ 0.3\%, Carbendazim50\%WP @ 0.1\%, Dinocap46\% EC @ 0.1\% Tridemorph80\% @ $0.05 \%$, water spray and control used for field experiment as per recommended doses. Spray suspension solution will be made separately by adding desired quantity in specified amount of water resulting into concentration normally recommended for spraying.

The observations were recorded for disease intensity of powdery mildew disease by $0-5$ scale, percent disease control, and average yield was recorded after harvest of the crop. Spraying was done at the initiation of disease and there after second spraying was undertaken at an interval of 15 days and observation was recorded at initiation of disease, after first, second and third spraying.

\section{Symptomology}

Regular observation of field was done and initiation of disease was recorded. Detailed study of symptoms of powdery mildew disease was done and observation recorded at initiation of disease after first, second and third spraying.

\section{Disease intensity}

Disease intensity was recorded at weekly interval on five okra plants randomly selected per treatment per replication. On each observation plant, bottom, middle and top leaves were selected for observation. Disease severity was recorded by applying 0 to 5 disease rating scale (Joi and Shinde, 1974) and percent disease severity was calculated by following formula.

\section{$\%$ Disease intensity $(\mathrm{PDI})=-\times 100$}

Number of leaves observed $\times$ maximum ratings

The percent disease control (PDC) was following formula. further calculated for each treatment by using

PDI in control- PDI in treatment

$\%$ Disease control $(\mathrm{PDC})=\longrightarrow 100$

PDI in control 
Okra crop was harvested regularly after its maturity. The fruit yields of $\mathrm{q}$ ha-1 were recorded. Incremental cost benefit ratios were calculated on increase yield over control. The each treatment cost was calculated by market rate and expenditure work out the ratio was calculated. The data of various observations were analyzed by the standard statistical method (Panse and Sukhatme, 1967). The null hypothesis was tested by ' $F$ ' test of significance to know whether treatment effects were real. The error (SE) and critical difference (CD) at 5\% level of probability were calculated.

\section{Results and Discussion}

Okra is an important vegetable crop grown in almost all the areas of the country. Among the fungal diseases affecting okra crop, powdery mildew caused by Erysiphaeci choracearum is one of the important and common occurrence wherever this crop is grown and causes considerable yield losses, however the success of crop is dependant to large extent on management of powdery mildew disease. Very limited work is carried out under Indian conditions so, pathological investigation leading to management have been carried out. Therefore to find out superior source for powdery mildew management an experiment on "Management of Powdery Mildew of Okra caused by Erysipheci choracearum" was conducted.

\section{Symptomology}

In the present investigation, the symptoms observed were resembled with those observed in natural infection. Disease initiates as white minute patches, first on the upper surface of lower leaves or older leaves and then spread to younger ones. While greyish powdery coating is visible on severely affected leaves. Leaves finally show necrosis resulting in withering, drying and defoliation. Similar observation also reported by Kothari and
Shekhawat (1972), Singh et al., (1988) and Vijaya (2004).

\section{Microscopic observation}

As the fungus Erysipheci choracearum is an obligate parasite, its characters were studied from the infected leaves by preparing semipermanent slides and observing the fungal structures under microscope. The conidia were formed singly or in short chains, which were barrel or cylindrical shape, hyaline, nonseptate. Conidia are produced in besipetal succession similar observations were recorded by (Singh, 1968).

\section{Effect of fungicides on powdery mildew intensity}

The field experiment was carried out to evaluate the efficacy of six fungicides with water spray and control for the management of powdery mildew disease of okra. Three sprayings were undertaken, first spray was done immediately after initiation of disease symptoms (40 DAS) and subsequent treatment sprays at an interval of 15 days were given and observations on disease intensity were recorded at 55 days, 70 days and 85 days after sowing. The powdery mildew disease intensity (PDI) recorded at initiation stage i.e., before spraying was ranged from 5.80 percent to 6.30 percent. Three sprays of fungicides was undertaken at 40 DAS, 55 DAS and 70 DAS with on interval of the disease as recorded after each spraying from each treatment was worked out.

The data presented in table 2 showed that minimum intensity of disease was observed in all treatments when compared with control. Among the fungicides minimum percent disease intensity was recorded with hexaconazole @ 0.1 percent $(10.78 \%)$, propiconazole @ 0.1 percent $(11.85 \%)$ \& wettable sulphur@0.3 percent $(12.71 \%)$ and were remains at par with each other and 
significantly superior over rest of treatments. Treatment 0.1 percent dinocap (15.06\%), 0.05 percent tridemorph $(16.17 \%)$ and 0.1 percent carbendazim $(18.16 \%)$ were also found significantly superior as compared with water spray and control and were statistically at par with each other in reducing the intensity of powdery mildew disease.

Table.1 Grading Scale

\begin{tabular}{|l|l|l|}
\hline Score & Description & Disease rating \\
\hline 0 & No symptoms & Immune \\
\hline 1 & $1-10$ percent leaf area affected & Resistant \\
\hline 2 & $11-25$ percent leaf area affected & Moderately resistant \\
\hline 3 & $26-50$ percent leaf area affected & Moderately susceptible \\
\hline 4 & $51-75$ percent leaf area affected & Susceptible \\
\hline 5 & Above 76 percent leaf area affected & Highly susceptible \\
\hline
\end{tabular}

Table.2 Efficacy of fungicides on intensity of powdery mildew and yield (q ha-1) of okra

\begin{tabular}{|c|c|c|c|c|c|c|c|c|c|}
\hline \multirow[b]{2}{*}{$\begin{array}{l}\text { Sr. } \\
\text { No. }\end{array}$} & \multirow[b]{2}{*}{ Treatments } & \multirow[b]{2}{*}{$\begin{array}{c}\text { Conc. } \\
(\%)\end{array}$} & \multicolumn{3}{|c|}{ \% Disease intensity } & \multicolumn{3}{|c|}{ \% Disease control } & \multirow[b]{2}{*}{$\begin{array}{c}\text { Yield(q } \\
\left.\text { ha }^{-1}\right)\end{array}$} \\
\hline & & & First spray & $\begin{array}{c}\text { Second } \\
\text { spray }\end{array}$ & Third spray & $\begin{array}{l}\text { First } \\
\text { spray }\end{array}$ & $\begin{array}{l}\text { Second } \\
\text { spray }\end{array}$ & $\begin{array}{l}\text { Third } \\
\text { spray }\end{array}$ & \\
\hline T1 & Hexaconazole & 0.1 & $28.56(32.27)$ & $22.71(28.43)$ & $10.78(19.16)$ & 34.92 & 57.52 & 87.33 & 54.29 \\
\hline $\mathrm{T} 2$ & Propiconazole & 0.1 & $31.82(34.32)$ & $25.55(30.34)$ & $11.85(20.12)$ & 27.50 & 52.21 & 86.08 & 48.48 \\
\hline T3 & WettableSulphur & 0.3 & $32.56(34.75)$ & $27.59(31.66)$ & $12.71(20.85)$ & 25.81 & 48.40 & 85.07 & 45.15 \\
\hline $\mathrm{T} 4$ & Carbendazim & 0.1 & $33.80(35.52)$ & $35.36(36.48)$ & $18.16(25.20)$ & 22.98 & 33.86 & 78.69 & 43.65 \\
\hline T5 & Dinocap & 0.1 & $33.74(35.51)$ & $28.56(32.26)$ & $15.06(22.83)$ & 23.12 & 46.58 & 82.31 & 43.01 \\
\hline T6 & Tridemorph & 0.05 & $34.48(35.93)$ & 28.81(32.26) & $16.17(23.69)$ & 21.43 & 46.11 & 81.00 & 41.54 \\
\hline $\mathrm{T} 7$ & Water spray & & $40.17(39.32)$ & $41.69(40.21)$ & $68.26(55.80)$ & 8.47 & 22.03 & 19.82 & 37.85 \\
\hline $\mathrm{T} 8$ & Control & & 43.89(41.49) & 53.47(46.99) & $85.14(67.54)$ & & -- & -- & 37.33 \\
\hline \multicolumn{3}{|c|}{ F test } & Sig. & Sig & Sig & & & & Sig. \\
\hline \multicolumn{3}{|c|}{ SEM \pm} & 1.36 & 1.29 & 1.52 & & & & 2.70 \\
\hline \multicolumn{3}{|c|}{$\mathrm{CD}(\mathrm{P}=0.05)$} & 3.93 & 3.74 & 4.42 & & & & 7.78 \\
\hline
\end{tabular}

(Figures in parenthesis are Arc sin values)

The results are match with the observation recorded by Dhuraj et al., (1999) recorded percent disease intensity (21.34\%) with the application of 0.05 percent hexaconazole while 0.025 percent propiconazole showed 23.77 percent disease intensity for control of fenugreek powdery mildew. Surwase et al., (2009) reported that hexaconazole 0.05 percent was most effective with 11.2 percent least disease intensity with maximum 70.46 percent disease control for management of pea powdery mildew. Dhutraj (2011) recorded 11.46 percent disease intensity in 0.1 percent carbendazim, 15.56 percent in 0.05 percent propiconazole and maximum percent disease control 62.40 percent with 0.25 percent wettable sulphur.

\section{Effect of fungicides on yield}

The data presented in table 2 indicates the differences due to various treatments on yield of okra fruits over control. Maximum yield $54.29 \mathrm{q} \mathrm{ha}^{-1}$ was obtained with 0.1 percent hexaconazole and 0.1 percent propiconazole achieve $48.48 \mathrm{q} \mathrm{ha}^{-1}$ which was at par with 
each other and significantly superior over rest of treatments. The yield obtained in control was $37.33 \mathrm{q} \mathrm{ha}^{-1}$ which have minimum difference as compared to water spray treatment resulted $37.85 \mathrm{q} \mathrm{ha}^{-1}$ yield. The observations were similar with Gupta and shyam (1998) observed maximum grain yield $3.65 \mathrm{~kg} /$ plot with application of 0.1 percent hexaconazole. khunti et al., (2002) reported highest yield $77.9 \mathrm{~kg}$ / ha in green gram with application of 0.05 percent hexaconazole. Patil et al., (2004) recorded maximum yield $7.0 \mathrm{q} / \mathrm{ha}$ with 0.1 percent propiconazole in fenugreek.

\section{References}

Benchasri, S. 2012. Okra (Abelmoschus esculentus (L.) Moench) as a valuable vegetable of the World. Ratar. Povrt., 49: 105-112.

Dhuraj, I.U., L.F. Akbari, R.R. Khandar and K.B. Jadeja. 1999. Field evaluation of fungicides against powdery mildew of fenugreek. J. Mycol. Pl. Pathol., 30(1): 98-99.

Dhutraj, D.N. 2011. Efficacy of fungicides and bioagents against powdery mildew of okra. J. Pl. Dis. Sci., 6(2): 170-172.

Gupta, S.K. and K.R. Shyam. 1998. Control of powdery mildew and rust of pea by fungicides. Indian Phytopath., 51(2): 184186.

Joi, M.B. and R.R.V. Shinde. 1974. Fungicidal control of powdery mildew of okra.
Pesticides, 13(2): 32-33.

Khunti, J.P., M.F. Bhoraniya and V.D. Vora. 2002. Management of powdery mildew and circospora leaf spot of mungbean by some systemic fungicides. J. Mycol. Pl. Pathol., 32(1): 103-105.

Kothari, K.L. and P.S. Shekhawat. 1972. Chemical control of powdery mildew of okra. The Indian J. Hort., 29(2): 235-236.

Panse, V.G. and P.V. Sukhatme. 1967. Statistical Methods of Agriculural Workers. ICAR Publication, New Delhi.

Patil, M.J., S.P. Ukey, B.T. Raut and B.V. Saoji. 2004. Efficacy of fungicides against powdery mildew of fenugreek. PKV Res. J., 28(2): 174-177.

Sastry, K.S.M. and S.J. Singh. 1974. Effect of yellow vein mosaic virus infection on growth and yield of okra crop. Indian Phytopath., 27: 294-297.

Singh, R.S. 1968. Plant Disease. Second Edition, Oxford and IBH Publication Co. Pvt. Ltd., New Delhi, pp. 176-177.

Singh, Shamsher, I.S. Bisht and A. Mujumdar. 1988. major viral, fungal and bacterial disease of bhendi and their control measures. Seed and Farm, 14(4): 27-28.

Surwase, A.G., D.R. Badgire and A.P. Suryawanshi. 2009. Management of pea powdery mildew by fungicides, botanicals and bioagents. Ann. Pl. Protec. Sci., 17(2): 384-388.

Vijaya, M. 2004. Chemical control of powdery mildew of okra. Indian J. Mycol. Pl. Pathol., 34(2): 604-605.

\section{How to cite this article:}

Parag Dahivelkar, G.E. Atre, P.V. Gawande and G.D. Mate. 2017. Management of Powdery Mildew of Okra Caused by Erysipheci choracearum. Int.J.Curr.Microbiol.App.Sci. 6(8): 31893193. doi: https://doi.org/10.20546/ijcmas.2017.608.380 